\title{
The Socio-Economic Impact of Land Use and Land Cover Change on the Inhabitants of Mount Bambouto Caldera of the Western Highlands of Cameroon
}

\author{
Formeluh Abraham Toh ${ }^{1 *}$, Tsi Evaristus Angwafo², Lawrence Monah Ndam ${ }^{3,4}$, \\ Mvondo Ze Antoine 5
}

\begin{abstract}
${ }^{1}$ Department of Forestry, Faculty of Agronomy and Agricultural Sciences, University of Dschang, Dschang, Cameroon ${ }^{2}$ Department of Fundamental Science, Higher Technical Teacher Training College (HTTTC), University of Bamenda, Bambili, Cameroon

${ }^{3}$ Department of Botany and Plant Physiology, University of Buea, Buea, South West Region, Cameroon ${ }^{4}$ Department of International Environmental and Agricultural Science, Faculty of Agriculture, Tokyo University of Agriculture and Technology, Tokyo, Japan

${ }^{5}$ Department of Soil Science, Faculty of Agronomy and Agricultural Sciences, University of Dschang, Dschang, Cameroon Email: ${ }^{*}$ formeluhat@gmail.com
\end{abstract}

How to cite this paper: Toh, F.A., Angwafo, T., Ndam, L.M. and Antoine, M.Z (2018) The Socio-Economic Impact of Land Use and Land Cover Change on the Inhabitants of Mount Bambouto Caldera of the Western Highlands of Cameroon. $A d$ vances in Remote Sensing, 7, 25-45. https://doi.org/10.4236/ars.2018.71003

Received: January 18, 2018 Accepted: March 26, 2018

Published: March 29, 2018

Copyright () 2018 by authors and Scientific Research Publishing Inc. This work is licensed under the Creative Commons Attribution International License (CC BY 4.0).

http://creativecommons.org/licenses/by/4.0/

\begin{abstract}
This work assessed the impact of land use and land cover (LULC) change on the socio-economic conditions of the inhabitants in the Mount Bambouto Caldera from 1980-2016. To achieve this, three time series satellite images; Landsat Thematic Mapper (TM) (1980), Landsat Enhanced Thematic Mapper (ETM) (2001), and Landsat 8 Operational Land Imager (OLI) (2016) scenes were employed to investigate the changes in LULC. The use of satellite images was supplemented with individual interviews, discussions with focus groups and key informants, and direct field observations. Five categories of LULC classes were identified namely: thick woody vegetation (natural forest and oil palms), light vegetation (croplands), savannah (grasslands), buildings (settlements), and bare grounds. The results showed that between 1980 and 2016, croplands, buildings and bare lands increased by $4 \%, 0.43 \%$ and $5.7 \%$ respectively while savannah/grassland and natural forest decreased by $4.4 \%$ and $5.8 \%$ respectively. Household survey revealed soil fertility decline and lack of credit schemes to be major constraints to crop production. Many religious holidays contribute to seasonal food shortages and the community faces a host of socio-economic and institutional challenges. Consequently, majority of households are destitute, live in abject poverty; which is an indication of the need for interventions by government and other development stakeholders to
\end{abstract}


tackle the problems of soil fertility, land use change and food insecurity.

\section{Keywords}

Land Use, Land Cover, Landsat, Bambouto Caldera, Socioeconomic Impact, Soil Fertility, Cameroon

\section{Introduction}

Concerns of land use and land cover (LULC) change and soil fertility problems in agricultural systems in Africa are factors that pull the attention of many researchers, and have been winning the interest of top policy makers in recent times [1] [2]. Human population pressure has primarily been the centre of blame for the widespread land use and land cover change and its associated environmental implications [3] [4] [5]. In developing countries like Cameroon, about $80 \%$ of the populace almost solely depend on natural resource exploitation for livelihood, and with increasingly competing demands for the utilization, development and sustainable management of land resources, LULC changes are very intensive and preoccupying [6]. LULC changes such as conversions of grasslands to croplands, fallowing croplands, and the change of infertile croplands to oil palm plantations are being practised as mitigative measures against the negative impact of soil fertility decline in Cameroon [7]. Although fertiliser application is recommended and practised by many farmers, improved fallow remains a preferred management strategy by many farmers to restore soil fertility as it is considered to be an affordable alternative [2] [6] [8]. In areas of high crop production potential, the land area for oil palms and cocoa plantations is rapidly expanding into productive croplands and natural forest. The expansion in favour of plantation crops is inspired by economic returns for livelihood enhancement and usually at the expense of agricultural lands and natural forest stands [7]. The high demand for palm oil in cities for consumption and biomass energy production and improved price of cocoa at the world market in recent years have further exacerbated the transformation of current natural forest, wetlands and marginal lands into plantations [9] [10]. As a result, land use change is gaining importance as land conversion practices are becoming more frequent in many parts of the country.

Remote Sensing (RS) with high-resolution satellite data has in recent times become widely and frequently applied in studies to establish land cover changes, obtain data on degradation levels of natural resource stocks (forests and wetlands, urbanization rates, agro-activity intensity), and other anthropogenically induced changes [4] [5] [11]. Unfortunately, such bio-physical approaches would not yield information as to the why of such changes. If land use and land cover studies would be understood, the inhabitants and their socioeconomic conditions, their preoccupations, livelihood strategies, perception on land, and 
other implications of socio-political, cultural, and biophysical nature and institutional factors must be given keen attention [12]. Therefore, for any meaningful study on sustenance of natural endowments, incorporation of the local experiences of members of the setting, key informants and focus groups in the community will provide information on past, present and expected future land use and land cover changes [13]. There is need to go interdisciplinary and examine possible methods for integrating LULC and social research. This justifies the integration of remote sensing and household survey as important tenets to enhance the study of the dynamics of changes in land use and land cover patterns and to obtain rapid, economically viable, reliable, and accurate results [13] [14]. According to Maro [12], one merit of using qualitative research in social science and survey research methods to understand local perceptions of land use change is its attempt to answer the questions "why change occurs" and "so what". Using individual semi-structured interviews with local farmers to understand the relation between national and local perceptions of environmental change in central Northern Namibia, Klintenberg et al. [15] observed that a combination of local and scientific knowledge provides a more useful assessment of land use and land cover change and its implications for local land-users and managers. Hence, integration of information from household surveys and data on land use and land cover changes obtained from remote sensing provides a vivid understanding of the causes and processes of LULC changes [16].

Studies related to LULC changes in Cameroon are rare, with most focusing on urban areas of the country [17]. There is a dearth of information on LULC change detections using remote sensing and GIS in different parts of the highlands of the country. Therefore, the objective of this study was to assess LULC changes from 1980-2016 and its implications on socioeconomic conditions and perceptions in the Mount Bambouto Caldera of the Western Highlands of Cameroon.

\section{Materials and Methods}

\subsection{Study Area}

The Mount Bambouto Caldera, located between latitudes $5^{\circ} 44^{\prime}$ and $5^{\circ} 36^{\prime} \mathrm{N}$ and longitudes $9^{\circ} 55^{\prime}$ and $10^{\circ} 07^{\prime} \mathrm{E}$, and extending from an altitude of $200 \mathrm{~m}$ to $2700 \mathrm{~m}$ above sea level, is typical of a multi-agricultural production system in the western highlands of Cameroon (Figure 1 and Figure 2). It receives between 2000 $3000 \mathrm{~mm}$ of rainfall annually and the mean monthly maximum and minimum temperatures are $32^{\circ} \mathrm{C}$ and $17^{\circ} \mathrm{C}$, respectively [18] [19]. This area is thus classified under Agroecological Zone IV in Cameroon (humid forest with monomodal rainfall) with two seasons; the long and heavy rainy season which runs from March to October, and a short dry season extending from November to February. As a consequence of heavy rainfall, the area is prone to geohazard perturbations, specifically frequent landslides that result in loss of vegetation, property and lives [19]. Recently, the landslide swarms of 20th July 2003 within 


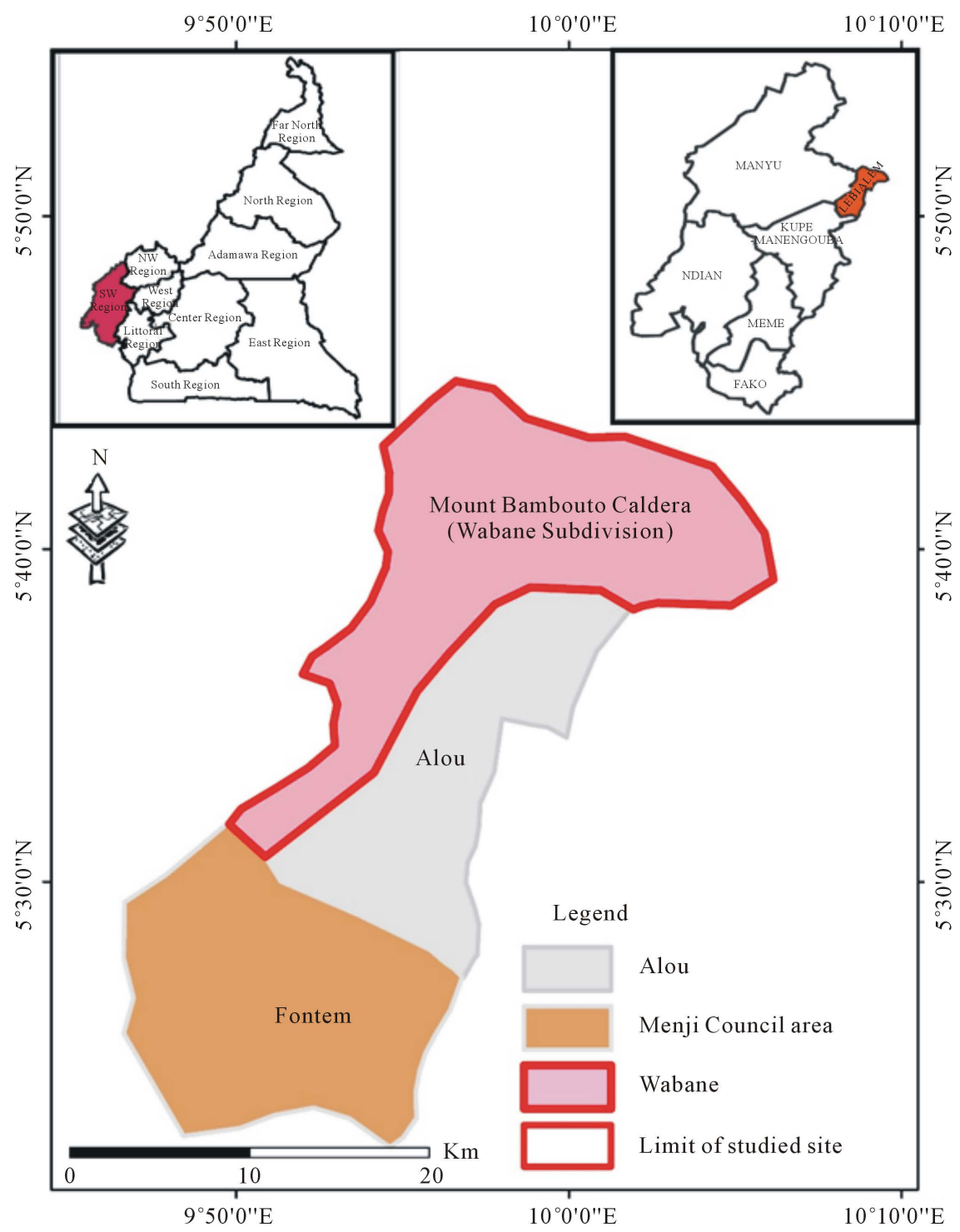

Figure 1. Location map of the Mount Bambouto Caldera (Wabane subdivision) in the western highlands of Cameroon.

the Caldera destroyed farmland, natural vegetation, settlements and caused a death toll of 23 persons and thousands of individuals displaced [20]. This perpetual events result in different land use options by the people as survival strategy and necessitates a comprehensive appraisal of LULC in the area.

The United Councils and Cities of Cameroon reported the population of the Mount Bambouto Caldera Area (Wabane Subdivision) by 2011 at 62,000 inhabitants with a population density of 35 persons per $\mathrm{km}^{2}$ [21]. The population is distributed into three geographic zones in village third class chiefdoms namely Agong, Fonenge, M'mouck Leteh, Atsualah, Magha, and Fomenji in the montane savannah zone, Bamumbu Central and the Banteng Area in the middle zone, and the Folepi, Bechati, Banti, Egumbo, Besali, Bangang, and Nkong in the forest lowland zone (Figure 2). This study site is predominantly inhabited by 


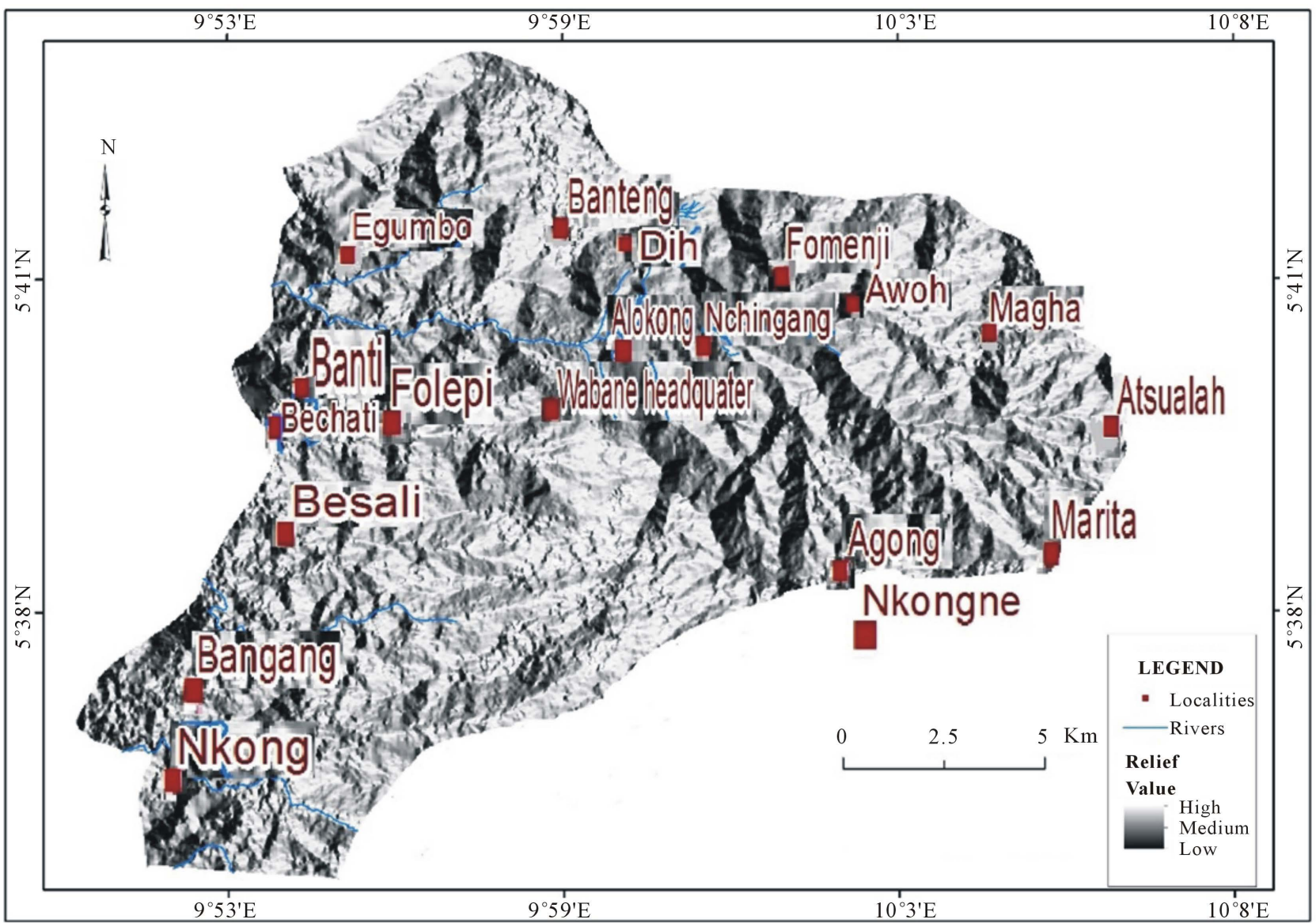

Figure 2. Topography and village settlements in the Mount Bambouto Caldera of the western highlands of Cameroon.

farmers belonging to the "Mundani" ethnic group, and over 95\% of the inhabitants rely on agriculture for sustenance.

The Soils in the Mount Bambouto Caldera have a pH range of 5.2 to 6.1, with soils in the montane savannah zone being more acidic than those in the submontane and lowland areas [20] [22]. Organic matter content ranges from 7 - 15 $\mathrm{g} \cdot \mathrm{Kg}^{-1}$ with the montane savannah soils nutrient richer than the lowland forest soils [23] [24]. Nutrient availability is averagely high in the entire area which is characterized by soils of volcanic origin. The tropical grassland and forest that had previously dominated the vegetation has gradually been replaced by croplands, settlements/agroforestry, and oil palm/cocoa plantations. Major crops grown in the Caldera are oil palms, cocoa, oranges, coconuts, plums, mangoes, plantains, bananas, cocoyams, maize, kolanuts, potatoes, carrots, cabbages, leaks, and garlics for consumption or commercial purposes. However, the area is averagely marked by a high external input-output farming system, with potato and cocoyam yields that exceed 5 tons per hectare in the montane savannah and submontane/lowland belts respectively. Relative to other parts of Cameroon, this enclave study site is amongst the most neglected areas in terms of agricultural innovation and infrastructural development, having very little governmental and non-governmental institutional support for the improvement of the livelihoods 
of the community. Interspersing the croplands in the study area, mosaic natural forests that belong to a tropical rainy afromontane forest characterize the landscape and some serve as sacred groves that host the deity of the people.

\subsection{Land Use and Land Cover Change Studies}

The principal data source of land use land cover classification and change analysis was remotely sensed data through a series of Landsat imagery. These included Landsat Thematic Mapper (TM), Landsat Enhanced Thematic Mapper (ETM) and Landsat Operational Land Imager (OLI) scenes of the year 1980, 2001, and 2016 respectively. These data sets were obtained from the University of Dschang, Cameroon Data Gateway of the Laboratory of Environmental Geomatics database. All the Landsat images were for the same month (December). The process involved imagery acquisition, processing and interpretation. Finally, ground-truthing for data validation was carried out through extensive and random field visits to cross-check the interpreted data with existing features and verifies the accuracy of interpreted data. Random stratified sampling of some land use and land cover categories like settlements, bare ground, croplands, woody vegetation and savannah were checked. Erroneous interpretations such as palm and cocoa plantations engulfed by woody vegetation and rain-fed agriculture with trees overshadowed by woody forest were noted for correction.

The reference data for the 2016 image for each land use land cover was collected from survey visits, topographic maps, and raw images. However, the reference data for the 1980 and 2001 images was collected through visual interpretation of the raw data of the Landsat images of the respective years, supplemented by field visits and purposive interviews of the elderly people in the study area.

\subsection{Household Surveys}

\section{Sampling and Survey Approach}

A household survey for socio-economic attributes and perceptions on land use and land cover change was carried out in two phases: July 2016 and July 2017, and adopted a purposive sampling approach in selecting sites for the study. This approach was used because of the peculiar agricultural systems employed in this study area (horticultural crop production and animal rearing systems in the top plateau savannah setting, and perennial food cropping and plantation systems in the middle and lower belts). In the first survey in July 2016, field observations were carried out to obtain background information on farming systems, land uses and the peoples' perception on land exploitation and management systems. During the survey, preparation and pre-testing of structured questionnaires was also done. In the second phase, the information gathered was used to re-design and administer 270 structured questionnaires for the collection of qualitative and quantitative data. Semi-structured face-to-face individual interviews, discussions with five focus groups and key informants (Figure 3) were used to generate information on land use types, soil fertility status, current soil management 


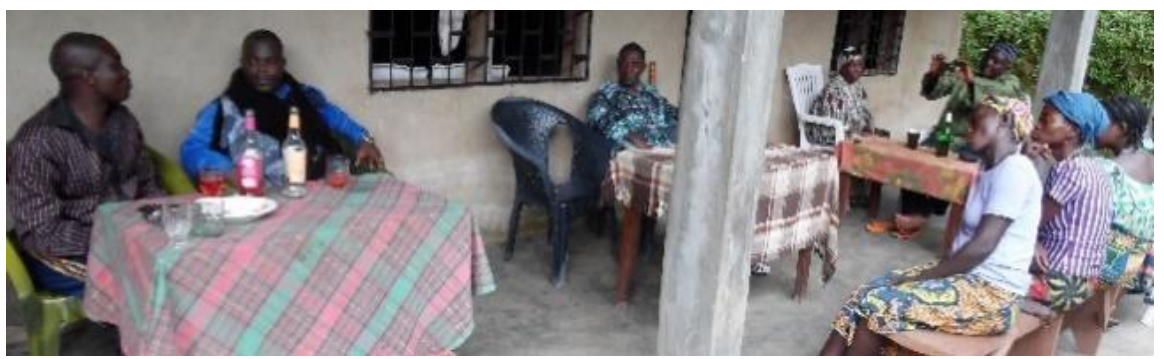

(a)

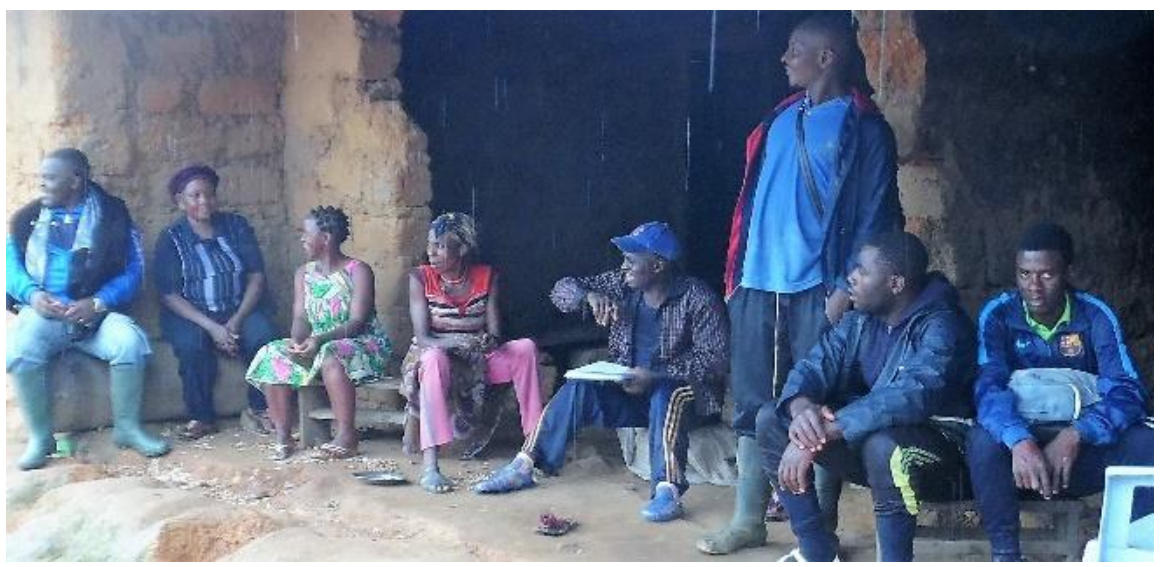

(b)

Figure 3. Focus group discussions in the Mount Bambouto Caldera of the western highlands of Cameroon. (a) Bangang Chief Palace and (b) NKong Chief Palace.

practices and related challenges, and the socioeconomic conditions of the people living in the study area.

From the peasant associations, 28 households were randomly selected for interview. Heads of the selected households, who are implicitly the decision makers and responsible for farm management were interviewed. Questions covered a wide range of socioeconomic issues and particularly those pertaining to household size, land size, land use types and changes that have occurred over time, and also perception about land use change with regard to the expansion of cropping and agroforestry systems. More so, unstructured interviews were carried out with four knowledgeable key informants recommended by the local farmer associations (Common Initiative Groups) including the Sub-divisional Delegate for Agriculture, the Director of Community Development, and some local traditional rulers. Field visits were conducted for ground truth checking and confidence building.

\subsection{Data Analyses}

The Geographic Information System (GIS) data was projected to the Universal Transverse Mercador (UTM) system, zone 37N and datum of World Geodetic System 84 (WGS 84), ensuring that there was consistency between data sets during analysis. The images were analysed by utilizing data image processing techniques in ERDAS image and ArcGIS $\odot 10.0$ software. The identity and loca- 
tion of some of the land use and land cover types such as grassland, crop/agricultural land, natural forest, settlements/agroforestry, and cocoa/palm plantations of the area were known based on the a priori knowledge of the research team and with ground truth data, a supervised signature extraction with maximum likelihood was used in the analysis. The pixel oriented classification with maximum likelihood method was used because it delivers better results than the minimum distance method [25]. The change analysis was conducted using post image comparison technique [26]. Ground-truthing was complemented with topographical maps of the area as well as field visits, interviews with individual and elderly people in the area. Rural settlements are scattered and associated with agroforestry and hence, settlements and agroforestry were classified together. The classified images were compared in two periods: 1980-2001, 2001-2016. Values were recorded in hectares and percentages. The percentage LULC changes were calculated using the equation:

$$
\text { \%LULC Change }=\frac{\text { Final Year Area }- \text { Initial Year Area }}{\text { Initial Year Area }} \times 100
$$

The household survey data was analysed using a statistical package for the social sciences (SPSS) version 20 (SPSS Inc., 2008) software. Descriptive statistics such as cross tabulation, frequencies and percentages were then employed to summarize the data.

\section{Results and Discussion}

\subsection{Land Use Land Cover}

The major land use land cover types identified include grasslands (savannah), croplands (light vegetation), settlements (Buildings) and agroforestry (thick woody vegetation), oil palm/cocoa plantations (thick woody vegetation) and fallow/natural forest (thick woody vegetation) as portrayed by the satellite images (Figures 4(a)-(c)). The figures show the trend of land use land cover change which is increasing in deforestation in preference to other land uses. The maps indicate drastic LULC changes over a period of 36 years of analysis. In 1980, forest was the dominant land use land cover type in the area. However, subsequent years were accompanied by a gradual and drastic decrease in the forest surface coverage as arable land and settlements consistently increase with population and the demand for diverse products and higher standards of living. This pushed farmers to increasingly convert part of their forest land to other land use types, particularly the opening of new farms and extension of existing ones.

As evidenced from the remotely sensed data, the proportionate spatial coverage of each LULC for 1980, 2001 and 2016 and the LULC changes from 1980 to 2001 and 2001 to 2016 are summarized in Table 1. In all three images, the dominant land cover remains thick woody vegetation that represents natural forest and fallow lands, palm/cocoa plantations, agroforestry around homes or in farms. Following this land cover in magnitude is light vegetation, which represents croplands or fields. It is also followed by savannah or grasslands, 


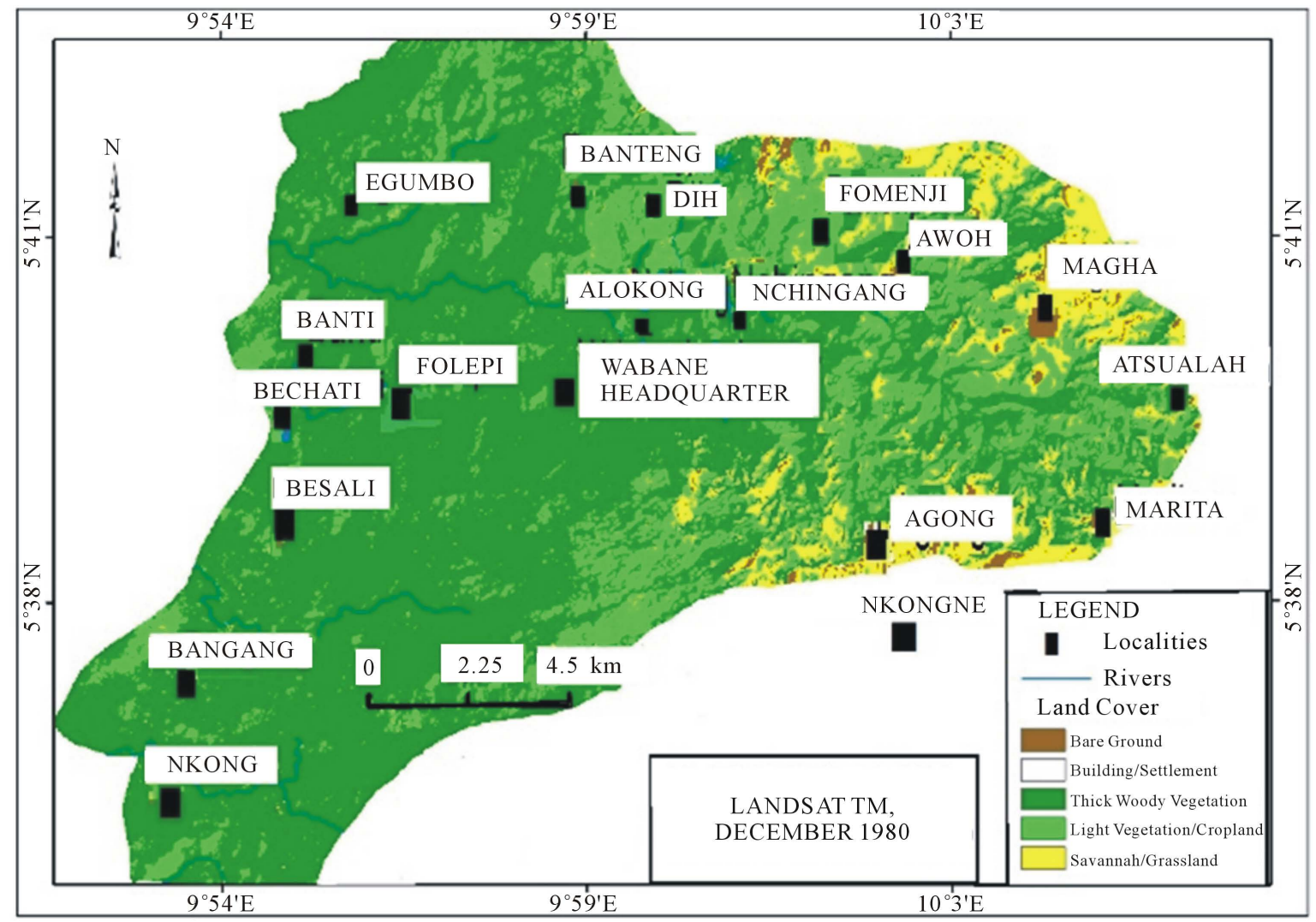

(a)

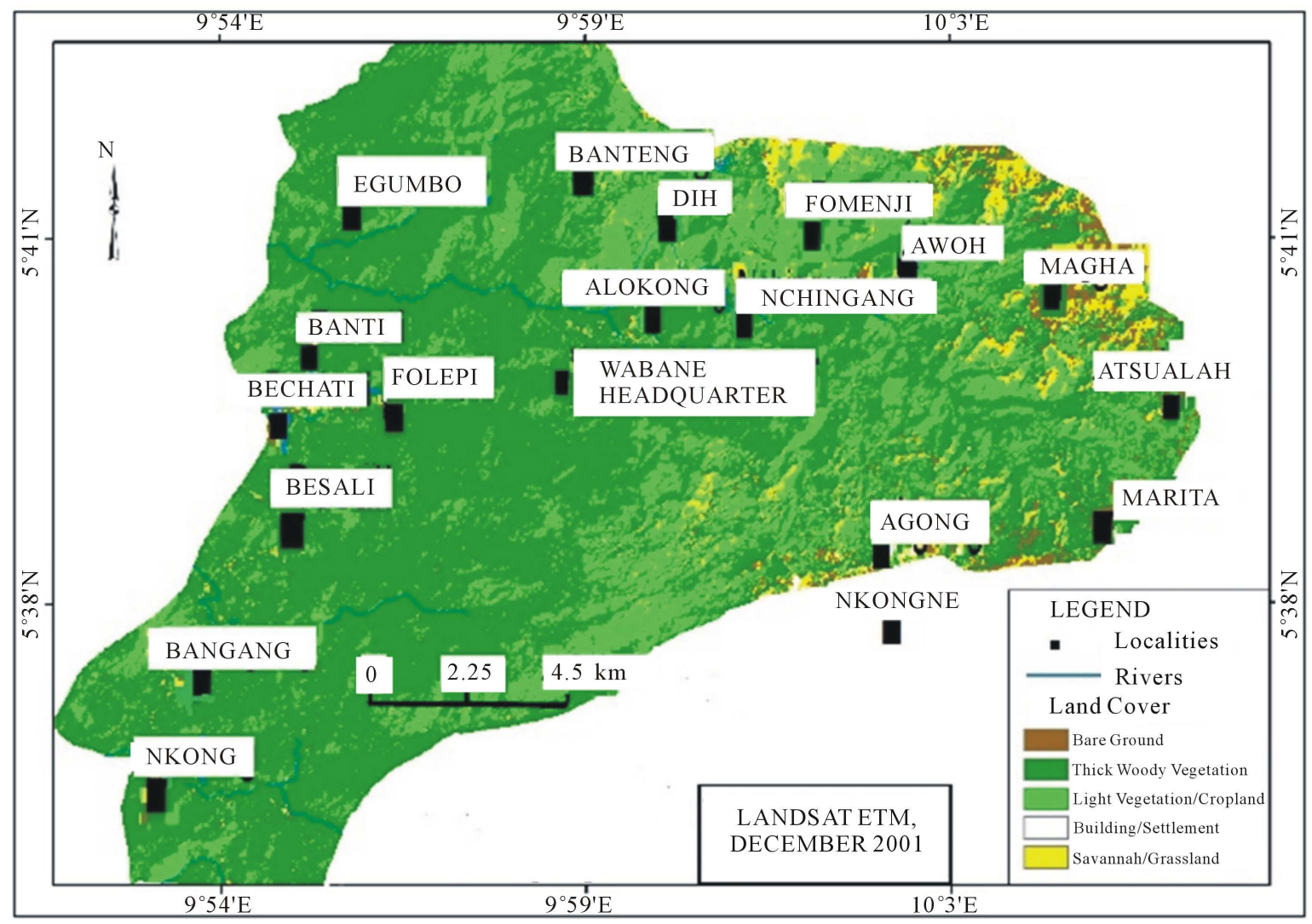

(b) 


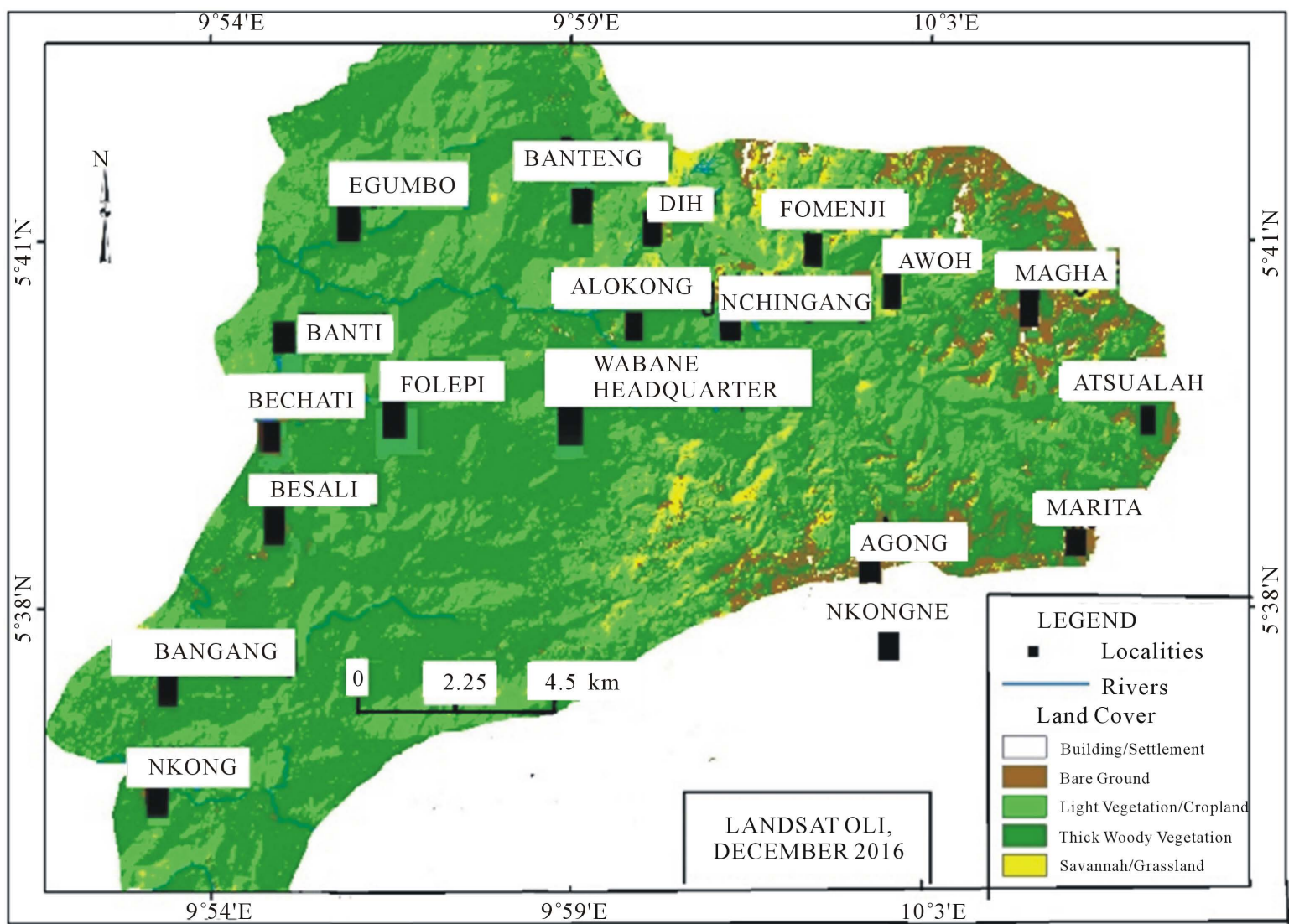

(c)

Figure 4. Satellite images of the Mount Bambouto Caldera of the western highlands of Cameroon showing land use land cover change. (a) 1980; (b) 2001; and (c) 2016.

Table 1. LULC changes from 1980 to 2001 and 2001 to 2016 showing area changes in hectares (Ha) and percentage LULC changes in the Mount Bambouto Caldera of the western highlands of Cameroon.

\begin{tabular}{|c|c|c|c|c|c|c|c|c|c|c|}
\hline \multirow{2}{*}{$\begin{array}{c}\text { Land use } \\
\text { land cover type }\end{array}$} & \multicolumn{2}{|c|}{1980} & \multicolumn{2}{|c|}{2001} & \multicolumn{2}{|c|}{2016} & \multicolumn{2}{|c|}{$1980-2001$} & \multicolumn{2}{|c|}{$2001-2016$} \\
\hline & Area/ha & $\%$ & Area/ha & $\%$ & Area/ha & $\%$ & $\begin{array}{c}\text { Change in } \\
\text { area/ha }\end{array}$ & $\begin{array}{c}\% \\
\text { change }\end{array}$ & $\begin{array}{l}\text { Change in } \\
\text { area/ha }\end{array}$ & $\begin{array}{c}\% \\
\text { change }\end{array}$ \\
\hline $\begin{array}{l}\text { Natural Forest/Oil Palms } \\
\text { (Thick Woody Vegetation) }\end{array}$ & 21441.8 & 68.8 & 21079.1 & 67.6 & 19642.0 & 63.0 & -362.7 & -1.2 & -1437.0 & -4.6 \\
\hline Grassland (Savannah) & 2950.6 & 9.5 & 1700.9 & 5.5 & 1590.6 & 5.1 & -1249.7 & -4.0 & -110.3 & -0.4 \\
\hline $\begin{array}{c}\text { Light } \\
\text { Vegetation/Croplands }\end{array}$ & 6359.2 & 20.4 & 7053.3 & 22.6 & 7603.4 & 24.4 & 694.1 & 2.2 & 550.1 & 1.8 \\
\hline Buildings & 6.1 & 0.02 & 79.0 & 0.3 & 133.9 & 0.4 & 72.9 & 0.23 & 54.9 & 0.2 \\
\hline Bare Ground & 412.2 & 1.3 & 1257.3 & 4.0 & 2199.9 & 7.1 & 845.0 & 2.7 & 942.7 & 3.0 \\
\hline Total & 31170 & 100 & 31170 & 100 & 31170 & 100 & 0 & 0 & 0 & 0 \\
\hline
\end{tabular}


which represent areas overwhelmingly dominated by grasses and sometimes intermingled with shrubs.

Bare grounds consists of various uncovered surfaces such as rock surfaces or recently cleared or burnt areas, only second to the least LULC which is buildings/settlement. The trend observed was: thick woody vegetation $>$ light vegetation $>$ grasslands/savannah $>$ bare grounds $>$ buildings/settlement. The percentage changes in LULC were generally greater for the period from 2001 to 2016 than the period 1980 to 2001. A succinct comparison of the land use land cover changes for the said years is also presented in Figure 5. Thick woody vegetation and grasslands/savannah were observed to decrease over the years while light vegetation/croplands, bare grounds and buildings/settlements increase.

In 1980, the total land surface cover was composed of natural forest and oil palms (woody vegetation), grasslands (savannah), croplands (light vegetation), buildings, and bare lands in the ratios $68.8 \%, 9.5 \%, 20.4 \%, 0.02 \%$, and $1.3 \%$ respectively. By 2001, natural forest and oil palm/cocoa plantations, grassland (savannah), cropland (light vegetation) buildings and bare lands occupied $67.6 \%$, $5.5 \%, 22.6 \%, 0.3 \%$, and $4.0 \%$ of the total land area, giving LULC change percentages of $-1.2 \%,-4.0 \%, 2.2 \%, 0.23 \%$, and $2.7 \%$ respectively from 1980 to 2001

1980, 2001, 2016 LULC

25000.0

20000.0

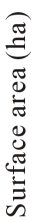

15000.0

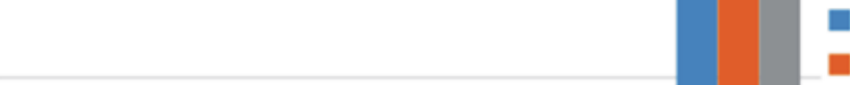

1980

2001

2016

惫

10000.0

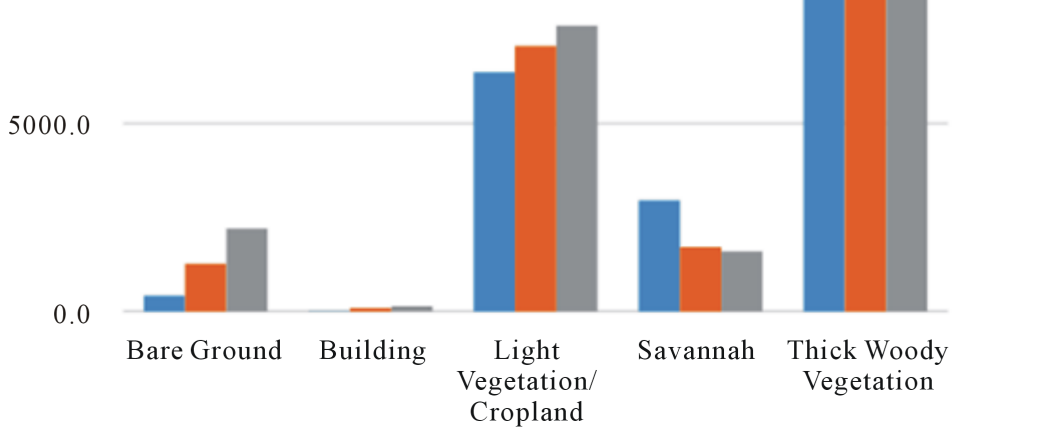

Figure 5. Comparison of Classified LULC from Landsat TM 1980, ETM 2001, and Landsat 8 OLI 2016 Imagery of Mount Bambouto Caldera of the Western Highlands of Cameroon. 
(Table 1). The negative values indicate a decrease in LULC change, the positive values indicating an increase in the LULC change. By 2016, natural forest and oil palms/cocoa plantations became 63.0\%, grassland (savannah) 5.1\%, croplands (light vegetation) $24.4 \%$, buildings $0.4 \%$, and bare lands $7.1 \%$, with corresponding LULC change percentages of $-4.6 \%,-0.4 \%, 1.8 \%, 0.2 \%$, and $3.0 \%$. In general, a comparison of the figures for 1980, 2001 and 2016 shows an increasing trend for bare lands, buildings and croplands, which are highly influenced if not totally orchestrated by anthropogenic activity. On the other hand, savannah and thick woody vegetation are on a decrease and this can equally be ascribed to increased exploitation of land resources, particularly the conversion of grasslands and natural forest to croplands, settlements and agroforestry, and the extension of palm/cocoa plantations.

Changes in land use patterns are triggered in the study area by different factors including better sources of income and duration of yield of proceeds from such preferred sources of income. Eleni et al. reported that planting trees especially eucalyptus on farmlands is considered by many farmers of the North Western Highlands of Ethiopia as a good source of income in a relatively short period of time [27]. The growth in croplands at the expense of other land uses observed in this study site has also been reported in numerous studies [11] [28] [29] [30] where the expansion of croplands and eucalyptus plantations at the expense of grasslands has been remarkable. However, this study revealed an increasing trend in bare grounds against other land use types, which is in line with Tekle and Hedlund [31] who reported increases in the sizes of open areas and settlements at the expense of shrub lands and forests in Kalu District, Southern Wello.

\subsection{Household Survey}

Two hundred and seventy (270) questionnaires were administered to $62 \%$ and $38 \%$ of men and women respectively spread across the age range of 20 to 70 years in the study area (Figures 6(a)-(c)). Also, 61\% and 39\% of the twenty-eight (28) interviews conducted were on men and women respectively. This trend of more men being interviewed than women can be explained by the fact that most women shy away from strangers, preferring the men to give such vital information about the community. More so, a greater fraction of the women are relatively less literate than the men and this makes them lack confidence in addressing matters of academics [32]. Information on questionnaire respondents such as civil status, household size, occupation, educational level, duration of stay in the community, social status, land size and land use was collected. More than $80 \%$ of the questionnaire respondents were aged between 20 and 60 years, which is the most active age group while less than $5 \%$ were above 70 years old. The observed population trend is a common phenomenon across the country and corroborates data on population stratification in Cameroon with $56 \%$ between 15 64 years and $3 \%$ above 65 years [21]. 


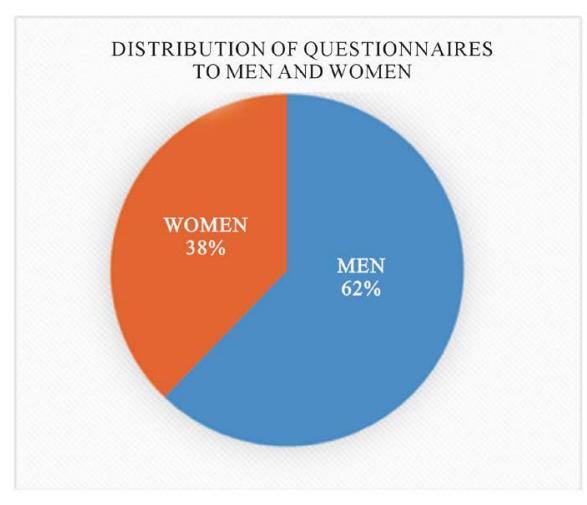

(a)
DISTRIBUTION OF QUESTIONNAIRES ACCORDING TO AGE RANCE

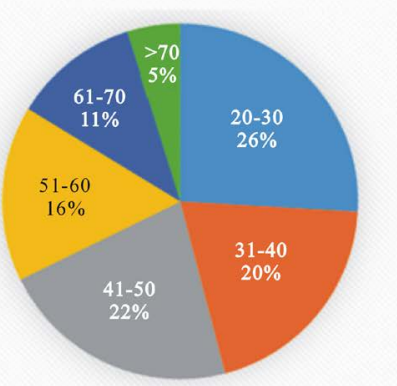

(b)

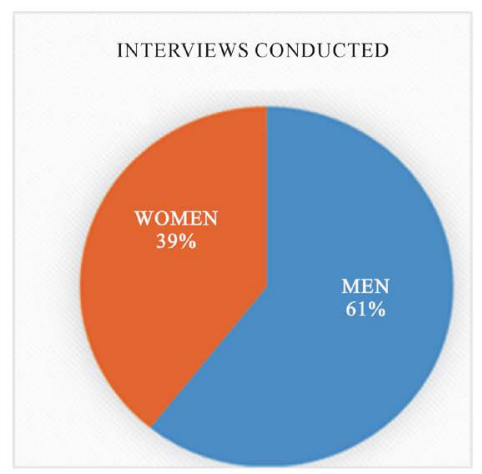

(c)

Figure 6. Distribution of questionnaires administered and interviews conducted during the study in the Mount Bambouto Caldera of the western highlands of Cameroon.

From the number of people interviewed, $90 \%$ were married and the main occupation of the people in the study site was farming. The average farm size per household was 2 ha and the maximum size recorded was 10 ha. Over $85 \%$ of the respondents were people of elementary education and early marriage is common in the Mount Bambouto Caldera, a factor that accounts for the high percentage of couples recorded. Farm size is determined by land tenure, and constrained by the hilly topography and enclave nature of the terrain. Similar results were recorded by Peter et al. [33] who opined that small farm sizes in Ethiopia are attributed to the mountainous and rocky state of the phytogeography of the country.

The key informants implicated in the study were the Director of Community Development for Wabane, Delegate of Agriculture for Wabane, the Mayor of Wabane, and some traditional rulers and elders. Direct field observations by the research team and focus group discussions conducted on important stakeholders like farmers' common initiative groups confirmed questionnaire responses on predominant land uses and agricultural management practices (Table 2), which included farming, agroforestry, and grazing/animal rearing. Such stakeholder groups consulted included the Wabane Cocoa Farmers' Cooperative Society, the Wabane Palm Oil Producers' Cooperative Society and the Mmock Potato Farmers' Cooperative Society. 


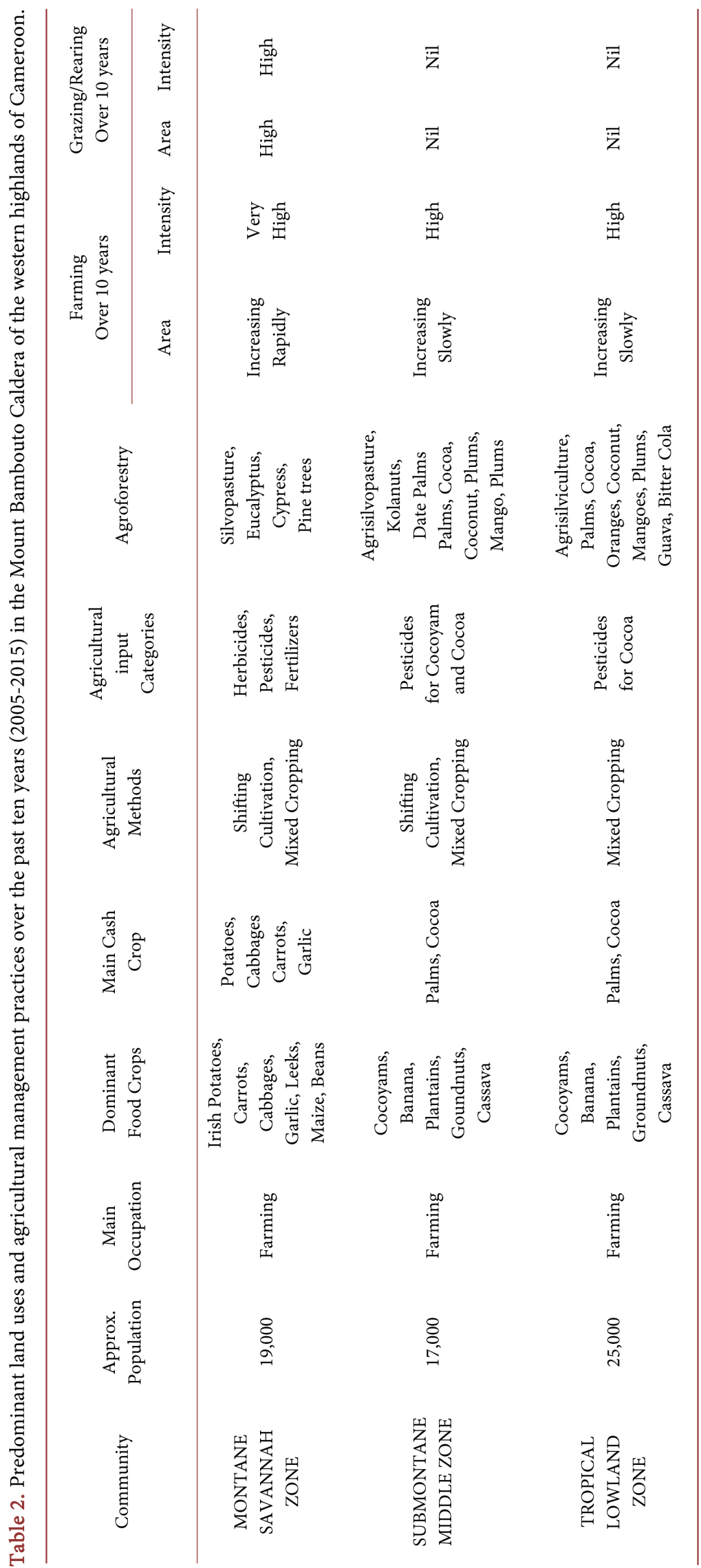


Agricultural management methods and forest exploitation over the past ten years (2005-2015) in the study area were recorded and summarized in Table 2. following the different geographical zones identified in the Mount Bambouto Caldera, which are marked by similar land use practices. In the montane savannah zone, submontane middle and tropical lowland regions, the agro-methods were principally dominated by shifting cultivation and mixed cropping, and mixed cropping with or without the use of agrochemicals respectively. It was observed that the distinctiveness of crops, methods of cultivation, agrochemical inputs, agroforestry, and trend of farming was in response to the altitudinal geographic variation of land. Farmed land surface area was found to be on the increase in response to increasing human population, particularly in the savannah montane zone where horticulture marked by monocultures of Irish potato, carrots and licks constitute the principal lucrative activity that has provided employment to the youth and drastically reduced rural exodus.

Agroforestry in the montane savannah zone is predominantly silvopasture with goats, sheep, cattle and the planting of eucalyptus, pine and cypress trees around homes for various uses including wind breaks, fence, and shade trees and the provision of timber and fuel wood. The lucrative farming activities have heightened the competition for land among inhabitants, particularly as most young men stay back in the village to do farming. Farming in the submontane zone is both for subsistence and economic gains with palm and cocoa plantations serving as the principal economic crops. In the tropical lowland zone, farming is largely palm/cocoa plantations mixed with subsistence agriculture. The importance of these plantations is seen in the engagement of the youthful population, as justified by their reluctance to go out of the village in search of jobs. Increase in farming surface area is only gradual, an indication of a low rate of population growth or diversification of occupation and economic activities. Agrisilviculture agroforestry system is practised mainly around settlements and to a lesser extent in farms, with one important function being shade trees particularly in the dry season when intense sunshine and high temperatures are often recorded. Animal grazing and rearing are conspicuously absent and the decreasing forest stock due to farming can be attributed to population growth and the quest for higher living standards.

\subsection{Household Survey}

Table 3 summarizes statistics of some household characteristics of the sample respondents. The average family size of the sample respondents was 7.8 persons. The average age of the sample farmers interviewed was 42.8 years while the farm size averages for poor and better-off farmers were 2.1 and 4.9 hectares respectively.

The farm size owned by the respondents varies from a minimum of about 0.5 hectare to a maximum of 10 hectares. It is worth noting that $53 \%$ of the respondents owned less than 4 hectares of land. Also, $29 \%$ and $71 \%$ of the respondents 
Table 3. Mean and standard deviation of some household characteristics in the Mount Bambouto Caldera of the western highlands of Cameroon.

\begin{tabular}{cccc}
\hline \multirow{2}{*}{ Household Characteristics } & \multicolumn{2}{c}{ Wealth class $\dagger$} & Total \\
\cline { 2 - 3 } & Poor & Better-off & \\
\hline Family Size & $6.2 \pm 2.41$ & $9.1 \pm 1.97$ & $7.8 \pm 2.40$ \\
Age of Interviewee & $40.1 \pm 10.1$ & $47.3 \pm 9.8$ & $42.8 \pm 10.2$ \\
$\quad$ Farm Size/ha & $2.1 \pm 1.30$ & $4.9 \pm 2.01$ & $3.3 \pm 2.11$ \\
$\begin{array}{c}\text { Average Area under oil } \\
\text { palms } / \text { ha }\end{array}$ & $2.1 \pm 1.18$ & $4.3 \pm 1.87$ & $2.9 \pm 2.11$ \\
$\begin{array}{c}\text { Average area under cocoa/ha } \\
\text { Average area under } \\
\text { cropland/ha }\end{array}$ & $1.3 \pm 1.02$ & $2.5 \pm 1.68$ & $1.9 \pm 1.05$ \\
Average grazing area & $1.1 \pm 1.01$ & $2.3 \pm 1.70$ & $1.5 \pm 1.03$ \\
\hline
\end{tabular}

Note: Family size refers to all persons per household resident at home during the interview, Farm size consists of all land held in one or more parcels and includes cropland, grassland, and fallow land and/or oil palm farm. ${ }^{*}$ It excludes community/association owned oil palm plantations. ${ }^{\dagger}$ Wealth class: poor $=$ respondents who suffer seasonal food shortages and have limited capacity to invest on farm land, better-off $=$ respondents relatively at better positions, rarely face food shortages and have the capacity to purchase agricultural inputs (seeds and agrochemicals). ${ }^{E}$ Grazing area estimated by both the poor (persons who cannot afford grazing) and better-off (those who can afford grazing).

were illiterate and people who are able to read and write respectively. Without considering community owned oil palm plantations, average area of land devoted for oil palms varies from 0.50 hectares for poor farmers to 6.0 hectares for better-off farmers.

Figure 7 presents results of sample respondents in prioritizing crop production constraints. Poor farmers ranked soil fertility decline (39.2\%) followed by shortage of land $(32.1 \%)$ as the main constraints to crop production. Whereas, better-off farmers ranked soil fertility decline (56.3\%) and lack of credit (28.9\%) as among the priority problems for crop production in the area. Overall, regardless of wealth class, $47.8 \%$ of the respondents declared soil fertility decline as the major obstacle to crop production in the area. This can be explained by the fact that farmers are poor and their desire to buy commercial fertilizers and other agrochemicals is hampered by lack of credit schemes. Accordingly, $22.4 \%$ of the total respondents mentioned the unavailability of credit schemes for purchase of agricultural inputs as one of the major obstacles to crop production. As a result, farmers adopt other options such as fallowing, conversions of grassland or forest land to cropland and infertile cropland to oil palm plantations as alternative measures against soil infertility problems in the area.

The fundamental reasons for the conversion of either cropland to oil palm farms or grassland/forest land to cropland in the study area include the demand for palm oil, decrease in productivity of land, and the generation of income for better living standards for a constantly growing population through the sale of palm oil and other agricultural produce. The main perceived causative factors of land use change from grassland to cropland, natural forest to palm plantation or 


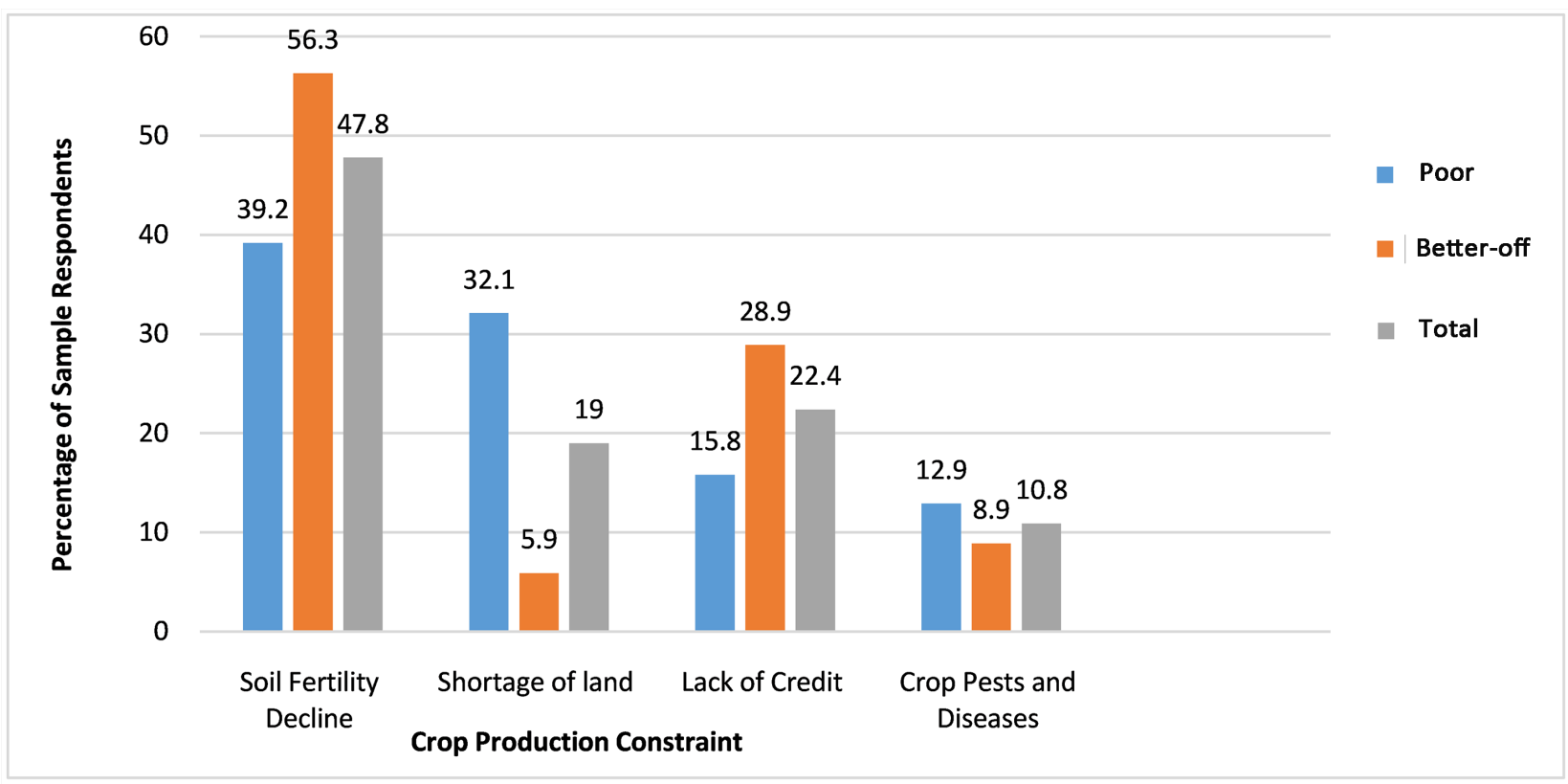

Figure 7. Crop production constraints prioritized according to wealth class in the Mount Bambouto Caldera of the western highlands of Cameroon.

cropland to oil palms are not only related to land degradation and lack of financial capacity, but also to multiple benefits of horticulture and/or oil palms for the community such as food supply and provision of employment that curbs rural exodus. Indeed, past socio-economic evaluations of oil palms in Cameroon confirmed that the planting of trees made a substantial contribution to the income of households [32].

Farmers' responses in prioritizing constraints to livestock production according to wealth class are presented in Table 4 . The most frequently cited and serious problem to livestock production in the area is shortage of livestock feed (42.6\%) and low productivity of local breeds (31.3\%). Shortage of livestock feed was more pronounced on poor farmers $(55.8 \%)$, whereas low productivity of local animals was more pronounced on better-off farmers (43.1\%).

Even though livestock feed shortages are a general problem in Cameroon, the case of the Mount Bambouto Caldera Area is amongst the most conspicuous as a result of rapid conversion of previous grasslands to either cropland or settlement, even as the demand for livestock increases with population growth.

The productivity of farmers in the study area is also greatly impacted upon by their religion and customs. Table 5 portrays the total number of holidays observed in a month together with the percentage proportion of respondents attesting to such days that farmers do not engage in farming activities. This consequently affects their output negatively. This is so because farmers in the area are either Christians or followers of the native custom and therefore obliged to observe a good number of religious holidays on which they are customarily prohibited from undertaking any cropping activities. Hence, $64 \%, 25 \%$ and $11 \%$ of the sample respondents do strictly observe these holidays for 16,12 and 8 days in 
Table 4. Respondents' prioritization of livestock production constraints in the Mount Bambouto Caldera according to wealth class.

\begin{tabular}{cccc}
\hline \multirow{2}{*}{ Main Constraint } & \multicolumn{3}{c}{ Wealth Class $\dagger$} \\
\cline { 2 - 4 } & Poor/\% & Better-off $/ \%$ & Total/\% \\
\hline Shortages of Livestock Feed & 55.8 & 29.4 & 42.6 \\
Low Productivity of Local Breeds & 19.6 & 43.1 & 31.3 \\
Animal Disease and Parasite & 9.8 & 18.6 & 14.2 \\
Lack of Credit Schemes & 8.8 & 6.4 & 7.6 \\
Shortages of Labour & 6.0 & 2.5 & 4.3 \\
Total & 100.0 & 100.0 & 100.0 \\
\hline
\end{tabular}

Table 5. Religious and related holidays observed each month during which farmers do not undertake farming activities in the Mount Bambouto Caldera of the western highlands of Cameroon.

\begin{tabular}{cccc}
\hline Category & $\begin{array}{c}\text { Religious Holidays } \\
\text { Observed/Week }\end{array}$ & $\begin{array}{c}\text { Religious Holidays } \\
\text { Observed/Month }\end{array}$ & $\begin{array}{c}\text { Percentage of } \\
\text { Farmers }\end{array}$ \\
\hline 1 & 02 & 08 & 11 \\
2 & 03 & 12 & 25 \\
3 & 04 & 16 & 64 \\
\hline
\end{tabular}

a month, respectively.

On the other hand, a very fascinating part of this study is that majority of the poor farmers interviewed reported to suffer from seasonal food shortages between 1-3 months in a year (mainly between crop planting and just before harvesting). In general, it was observed that the religious holidays constrain labour availability for cropping during the peak demand period, and therefore, is directly responsible for the current food insecurity problem in the study area amongst other constraints.

\section{Conclusions}

Remote sensing and GIS analysis results revealed a gradual but very significant decrease in the surface area of grasslands and natural forest from 1980 to 2016 that was accompanied by an increase in the surface area of croplands, settlements/agroforestry, and bare lands in the same period. Steady population growth, the quest for diverse products in order to diversify incomes sources, and soil fertility decline over time exacerbated by constant landslides in the rainy season are the propelling factors behind farmers changing part of their land to other forms of land use. The declining soil fertility, which is primarily caused by soil erosion and regular cultivation coupled with the lack of financial capacity for its restoration account for the majority of the household food insecurity in the area. Therefore, the way forward in soil fertility management in this area would require the application of technologies that add nutrients to the soil. Such 
technologies should be complemented by measures that reduce nutrient losses, particularly, through runoff and soil erosion on steep slopes and practices that hinder mass movements.

Due to the proximity of the study area to major markets (surrounding towns of Dschang, Bafoussam, Mbouda and Bamenda), building public-private partnerships around market-oriented oil palm production and horticultural food crops in general can be an entry point for encouraging investment in the use of external nutrient inputs to improve soil fertility and boost agricultural productivity. The cultural practice and enforcement of too many religious holidays in the study area reduce the availability of labor and so contributes directly to the seasonal food shortages experienced in the community. This points to the need for government and local officials to intervene through discussions with religious leaders and community elders to reduce the number of religious holidays in the area.

The results of this study provide compelling evidence that the local community in the study area is faced with a host of social, economic and institutional challenges which need to be properly addressed in seeking solutions to the problems of food insecurity in this area. Therefore, we highly recommend the involvement of interdisciplinary stakeholders and policy framework in a bid to revert the current dire situation, looking from both the biophysical and social perspectives. In particular, education and capacity building of the local inhabitants with different and novel agricultural technologies will not only tackle the problem of food security but also greatly contribute to environmental protection in the future.

\section{Acknowledgements}

Special appreciation for this work goes to the head of the University of Dschang Laboratory of Environmental Geomatics for the provision of the Landsat images, the Mayor and traditional authorities who gave administrative clearances and also served as key informants, including the Director of Community Development and Suddivisional Delegate for Agriculture for Wabane, heads of the local farmer associations (Common Initiative Groups) consulted as focus groups. Special thanks go to Follah, Fon of Bangang, and Chief Taliteba of Banti, Fontalewunta of Bechati and Mr. Fongoh Mathias of Magha for their hospitality.

\section{References}

[1] Kassa, T., Anton, V.R. and Jean, P. (2013) Assessing the Role of Policies on Land Use Change and Agricultural Development since 1960s in Northern Ethiopia. Land Use Policy, 30, 944-951. https://doi.org/10.1016/j.landusepol.2012.07.005

[2] Nair, P.K.R. (2014) Grand Challenges in Agroecology and Land Use Systems. Frontiers in Environmental Science, 2, 4. https://doi.org/10.3389/fenvs.2014.00001

[3] Ramankutty, N., Foley, J.A. and Olejniczak, N.J. (2002) People on the Land: Changes in Global Population and Croplands during the $20^{\text {th }}$ Century. AMBIO: $A$ Journal of the Human Environment, 31, 251-257. 
https://doi.org/10.1579/0044-7447-31.3.251

[4] Barasa, B., Egeru, A., Okello, P. and Mutuzo, F. (2010) Dynamics of Land Use/Cover Trends in Kanungu District, South-Western Uganda. Journal of Applied Sciences and Environmental Management, 14, 67-70.

[5] Wubie, M.A., Assen, M. and NicoLau, M.D. (2016) Patterns, Causes and Consequences of Land Use/Cover Dynamics in the Gumara Watershed of Lake Tana Basin, Northwestern Ethiopia. Environmental Systems Research, 5, 8.

https://doi.org/10.1186/s40068-016-0058-1

[6] Desalegn, T., Cruz, F., Kindu, M., Turrión, M.B. and Gonzalo, J. (2014) Land-Use/Land-Cover (LULC) Change and Socioeconomic Conditions of Local Community in the Central Highlands of Ethiopia. International Journal of Sustainable Development \& World Ecology, 21, 406-413.

https://doi.org/10.1080/13504509.2014.961181

[7] Hoyle, D. and Levang, P. (2012) Oil Palm Development in Cameroon. An Ad Hoc Working Paper, WWF in Partnership with IRD and CIFOR, Cameroon, $16 \mathrm{p}$.

[8] Tematio, P., Tsafack, E.I. and Kengni, L. (2011) Effects of Tillage, Fallow and Burning on Selected Properties and Fertility Status of Andosols in the Mount Bambouto, West Cameroon. Agricultural Science, 2, 334-340. https://doi.org/10.4236/as.2011.23044

[9] Carr, D.I. (2004) Tropical Deforestation. In: Janelle, D.G. and Hansen, K., Eds., WorldMinds. Geographical Perspectives on 100 Problems, Springer, Dordrecht, 293-298. https://doi.org/10.1007/978-1-4020-2352-1_47

[10] Bainkong, G. (2010) Palm Oil Production: Government Launches Modernisation Project. Cameroon Tribune, 19th Edition, $14 \mathrm{p}$.

[11] Dessie, G. and Kleman, J. (2007) Pattern and Magnitude of Deforestation in the South Central Rift Valley Region of Ethiopia. Mountain Research and Development, 27, 162-168. https://doi.org/10.1659/mrd.0730

[12] Maro, P. (2011) Environmental Change in Lesotho: An Analysis of the Causes and Consequences of Land-Use Change in the Lowland Region. Springer, Dordrecht. https://doi.org/10.1007/978-94-007-1881-4

[13] Gashaw, T., Tulu, T., Argaw, M. and Abeyou, W. (2017) Evaluation and Prediction of Land Use/Land Cover Changes in the Andassa Watershed, Blue Nile Basin, Ethiopia. Environmental Systems Research, 6, 17.

https://doi.org/10.1186/s40068-017-0094-5

[14] Sertel, E., Findik, N., Kaya, S., Seker, D.Z. and Samsunlu, A. (2008) Assessment of Landscape Changes in the Kizilirmak Delta, Turkey, Using Remotely Sensed Data and GIS. Environmental Engineering Science, 25, 353-362.

https://doi.org/10.1089/ees.2006.0149

[15] Klintenberg, P., Seeley, M. and Christianson, C. (2007) Local and National Perceptions of Environmental Change in Central Northern Namibia: Do They Correspond? Journal of Arid Environments, 69, 506-525. https://doi.org/10.1016/j.jaridenv.2006.10.015

[16] Benoît, M., William, D.S., Ousseynou, N. and Lambin, E.F. (2000) Impact of Macroeconomic Change on Deforestation in South Cameroon: Integration of Household Survey and Remotely-Sensed Data. World Development, 28, 983-999. https://doi.org/10.1016/S0305-750X(00)00007-3

[17] Balgah, S.N. (2013) Land Tenure and Land Use Dynamics in Limbe City, South West Region of Cameroon. Agriculture Science Developments, 2, 14-24.

[18] Nkembi, L., Skeen, R. and Ndeloh, D. (2006) The Lebialem Highlands Montane 
Birds' Conservation Project, Cameroon. Final Report for Rufford Foundation, UK, The Environment and Rural Development Foundation (ERuDeF).

[19] Ayonghe, S.N. and Ntasin, E.B. (2008) The Geological Control and Triggering Mechanism of Landslides of the 20th July 2003 within the Bambouto Caldera, Cameroon. Journal of the Cameroon Academy of Sciences, 7, 191-203.

[20] Ntasin, E.B., Ayonghe, S.N. and Suh, E.C. (2008) The 20th July 2003 Landslide Swarms within the Bambouto Caldera, Cameroon and Their Effects. 1st World Landslide Forum, Tokyo, 18-21 November, 2008.

[21] UCCC (2014) Wabane Council Area. United Councils and Cities of Cameroon. http://www.cvuc.cm/national/index.php/fr/carte-communale/region-du-nord/579wabane

[22] Youmen, D. (1994) Evolution volcanologique, pétrologique et temporelle de la caldeira des monts Bambouto (Cameroun). Thèse, Christian-Albrechts-Universität zu Kiel, Kiel, Allemagne, 274 p.

[23] Tabi, F.O., Bitondo, D., Yinda, G.S., Kengmegne, S.S.A. and Ngoucheme, M. (2013) Effect of Long-Term Integrated Soil Fertility Management by Local Farmers on $\mathrm{Nu}$ trient Status of a Typic Dystrandept under Potato-Based Cropping System. International Research Journal of Agricultural Science and Soil Science, 3, 134-140.

[24] Jiomeneck, P.S., Tematio, P., Wilson, M.A. and Yemefack, M. (2011) Andosolization of Soils on a Strombolian Cone at Mount Bambouto, Cameroon. Open Journal of Soil Science, 1, 97-105. https://doi.org/10.4236/ojss.2011.13013

[25] Gomarasca, M. (2010) Basics of Geomatics. Applied Geomatics, 2, 137-146. https://doi.org/10.1007/s12518-010-0029-6

[26] Singh, A. (1989) Digital Change Detection Techniques Using Remotely-Sensed Data. International Journal of Remote Sensing, 10, 989-1003. https://doi.org/10.1080/01431168908903939

[27] Eleni, Y., Wolfgang, W., Michael, E.K., Dagnachew, L. and Günter, B. (2013) Identifying Land Use/Cover Dynamics in the Koga Catchment, Ethiopia, from Multi-Scale Data, and Implications for Environmental Change. ISPRS International Journal of Geo-Information, 2, 302-323. https://doi.org/10.3390/ijgi2020302

[28] Kamusoko, M.A. (2007) Land Use/Cover Change and Landscape Fragmentation Analysis in the Bindura District, Zimbabwe. Land Degradation \& Development, 18, 221-233. https://doi.org/10.1002/ldr.761

[29] Paré, S., Söderberg, U., Sandewall, M. and Ouadba, J.M. (2008) Land Use Analysis from Spatial and Field Data Capture in Southern Burkina Faso, West Africa. Agriculture, Ecosystems \& Environment, 127, 277-285. https://doi.org/10.1016/j.agee.2008.04.009

[30] Zhao, S., Peng, C., Jiang, H., Tian, D., Lei, X. and Zhou, X. (2006) Land Use Change in Asia and the Ecological Consequences. Ecological Research, 21, 890-896. https://doi.org/10.1007/s11284-006-0048-2

[31] Tekle, K. and Hedlund, L. (2000) Land Cover Changes between 1958 and 1986 in Kalu District, Southern Wello, Ethiopia. Mountain Research and Development, 20, 42-51. https://doi.org/10.1659/0276-4741(2000)020[0042:LCCBAI]2.0.CO;2

[32] Focho, D.A., Ndam, W.T. and Fonge, B.A. (2009) Medicinal Plants of Aguambu-Bamumbu in the Lebialem Highlands, Southwest Province of Cameroon. African Journal of Pharmacy and Pharmacology, 3, 1-13.

[33] Peter, J.L., Haileslassie, A., Joerg, A.P. and Veldkamp, E. (2007) Nutrient Flows and Balances at the Field and Farm Scale: Exploring Effects of Land-Use Strategies and Access to Resources. Agricultural Systems, 94, 459-470. https://doi.org/10.1016/j.agsy.2006.11.013 